\title{
Feminine Private Shows of the Qājār Era: A Feminist Approach
}

\author{
Alma Moradi-Goshtasb ${ }^{1}$, Behrooz Mahmoodi-Bakhtiari ${ }^{2}$ \\ University of Tehran ${ }^{1,2}$
}

\begin{abstract}
Historical evidence delineates that Iranian women in the Qājār era (late $18^{\text {th }}$ century Iran) had spent most of their time in the interior rooms of their houses due to the social conditions of that time, and their hobbies confined to a combination of imitations and feministic burlesque shows. Overtime, these games changed to a kind of theatrical (or let's say, Performing) tradition, and had turned to a secure place to express the women's opinions and ideologies, together with their approach to the discriminatory views about their social class. Such plays have been collected and studied briefly by a couple of anthropologists; however, it seems that this performing tradition has not received a detailed study within a theoretical framework. Therefore, this research aims to investigate this special theatrical performance in Qajar era in Iran, with respect to theories of feminist studies, and presents a historical evaluation of such performances in some literary works. The purpose of this study is three-fold: First, to show whether it is possible to find traces of reaction and dissent towards inappropriate conditions of women in the joyful performances of women of the Qājār era, Secondly, to see whether these performances are capable of being understood through Bakhtin's readings of feminism, and finally, and most importantly, to see if any traces of feminist self-consciousness may be followed in these performances. Keywords: Qājār era, burlesque shows, feminism
\end{abstract}


